\title{
PENGARUH EKSTRAK ETHANOL PROPOLIS TERHADAP KSPRESI PROTEIN CASPASE 8, APOPTOSIS, DAN PROLIFERASI PADA KULTUR SEL ADENOKARSINOMA KOLON (WiDr)
}

\author{
THE EFFECT OF PROPOLIS ETHANOL EXTRACT ON CASPASE 8 PROTEIN \\ EXPRESSION, APOPTOSIS, AND PROLIFERATION IN ADENOCARCINOMA COLON \\ CELL (WiDr)
}

\author{
Gigih Rahmandanu P, Paulus Kusnanto, Bambang Purwanto \\ Sub Bagian Gastroentero Hepatologi, Bagian Ilmu Penyakit Dalam \\ FK UNS / RSUD Dr. Moewardi Surakarta
}

Korespondensi: dr. Gigih Rahmandanu P, Sp. PD. Email: dr.gigih@yahoo.com

\begin{abstract}
ABSTRAK
Kanker kolorektal merupakan kanker terbanyak ketiga pada pria, kedua pada wanita, dan menjadi penyebab kematian keempat, sekitar 8\% dari penyebab kematian karena kanker. Sebagian besar pasien kanker kolorektal didiagnosis dalam stadium yang sudah tidak dapat dioperasi. Propolis diketahui memiliki aktivitas anti kanker. Mekanisme anti kanker propolis melalui induksi apoptosis dan juga melalui penghambatan proliferasi dalam siklus sel. Penelitian ini bertujuan untuk mengkaji efek anti kanker ekstrak ethanol propolis (EEP) yang berasal dari Kerjo, Karanganyar, Indonesia pada kultur sel adenokarsinoma kolorektal (cell line WiDr) melalui pengaruhnya terhadap ekspresi protein Caspase 8, apoptosis dan proliferasi sel. Penelitian ini merupakan penelitian experimental laboratories, post test with control group design. Penelitian dilakukan pada kultur sel WiDr dengan perlakuan pemberian dosis ekstrak ethanol propolis, kontrol positif (5-FU), kombinasi ekstrak ethanol propolis dengan 5-FU, dan kontrol negatif (tanpa obat). Pengamatan ekspresi protein Caspase 8 dilakukan dengan metode imunositokimia, pengamatan apoptosis dilakukan dengan double staining menggunakan pewarnaan akridin oranye-etidium bromide, sedangkan pengamatan proliferasi menggunakan MTT assay dengan doubling time. Hasil Penelitian menunjukkan bahwa EEP cenderung menekan viabilitas sel WiDr dengan $\mathrm{IC}_{50}$ sebesar $140 \mu \mathrm{g} / \mathrm{mL}$. EEP konsentrasi 70,140, $280 \mu \mathrm{g} / \mathrm{mL}$ mampu meningkatkan ekspresi protein Caspase 8 dan menginduksi apoptosis yang sebanding dengan peningkatan konsentrasi yang diberikan. EEP konsentrasi $70 \mu \mathrm{g} / \mathrm{mL}$ dapat menghambat proliferasi sel sebanding dengan EEP konsentrasi 140 dan $280 \mu \mathrm{g} / \mathrm{Ml}$. Penelitian ini menunjukkan EEP mampu menekan viabilitas sel WiDr. Aktivitas ini kemungkinan terkait dengan kemampuannya dalam meningkatkan ekspresi protein Caspase 8 dan apoptosis sebanding dengan peningkatan konsentrasi yang diberikan. EEP pada konsentrasi terkecil yang diuji $(70 \mu \mathrm{g} / \mathrm{mL})$ mampu menghambat proliferasi pada sel WiDr sebanding dengan dosis yang lebih tinggi.
\end{abstract}

Kata kunci: EEP, Caspase 8, apoptosis, proliferasi, cell line WiDr

\section{ABSTRACT}

Colorectal cancer is the third most common cancer in men, second in women, and the fourth leading cause of death, about $8 \%$ of death due to cancer. Most colorectal cancer patients are diagnosed in an inoperable stage. Propolis is known to have anti-cancer activity, through the induction of apoptosis and the inhibition of proliferation in the cycle cell. This study is aimed to assess the anti-cancer effects of ethanol extract of propolis (EEP) originating from Kerjo, Karanganyar, Indonesia in colon adenocarcinoma cell culture (WiDr) through its effects on the expression of Caspase 8 protein, apoptosis, and cell proliferation. This study was an experimental research laboratories, post-test with control group design. The study was conducted on cell culture of WiDr with treatment of ethanol propolis extract dose, positive control (5-FU), combination of ethanol propolis extract with 5-FU, and negative control (without drug). Caspase 8 protein expression was conducted using immunocytochemistry, apoptosis performed by double staining using acridine orange staining - ethidium bromide, while observations of proliferation using MTT assay with doubling time technique. The results showed that EEP tends to suppress the viability of WiDr cells with $I C_{50}$ of $140 \mu \mathrm{g} / \mathrm{mL}$. EEP concentrations of 70.140, $280 \mu \mathrm{g} / \mathrm{mL}$ were able to increase 
the expression of the Caspase 8 protein and induce apoptosis which was proportional to the increase in the given concentration. EEP concentrations of $70 \mu \mathrm{g} / \mathrm{mL}$ may inhibit cell proliferation proportional to EEP concentrations of 140 and $280 \mu \mathrm{g} / \mathrm{Ml}$. This study showed EEP was able to suppress the viability of WiDr cells. This activity was probably related to its ability to increase the expression of the Caspase 8 protein and apoptosis in proportion to the increase in concentration provided. EEP at the smallest concentration tested $(70 \mu \mathrm{g} / \mathrm{mL})$ was able to inhibit the proliferation of WiDr cells in proportion to higher doses.

Keywords: Ethanol extract of propolis, Caspase 8, apoptosis, proliferation, WiDr cells.

\section{PENDAHULUAN}

Kanker merupakan penyebab kematian nomor 2 di seluruh dunia, nomor 3 di negara berkembang. Diperkirakan ada 14,1 juta kasus kanker baru dan 8,2 juta kematian karena kanker di seluruh dunia, khusus di Asia Tenggara sekitar 785.400 kasus. (Ferlay et al., 2015).

Kanker kolorektal merupakan kanker terbanyak ketiga pada pria, kedua pada wanita, dan menjadi penyebab kematian keempat, sekitar 8\% dari penyebab kematian karena kanker (Scholefield dan Eng, 2014). Modalitas tata laksana kanker kolorektal meliputi operasi, radioterapi dan kemoterapi (Young et al., 2011). Sebanyak 20\% dari kasus kanker kolorektal yang telah metastasis pada umumnya tidak dapat diperasi dan relatif sulit disembuhkan dengan 5-year survival rate sebesar 12\% (Wang dan Zhang, 2014). Sehingga terapi kanker kolorektal masih menjadi tantangan hingga saat ini.

Propolis merupakan produk alami dari lebah yang telah lama digunakan untuk pengobatan tradisional (Frozza et al., 2013). Propolis, disebut adalah suatu zat yang dihasilkan oleh lebah madu, mengandung resin dan lilin lebah, bersifat lengket yang dikumpulkan dari sumber tanaman, terutama dari bunga dan pucuk daun, untuk kemudian dicampur dengan air liur lebah (Marcucci et al., 2001; Salatino et al., 2005; Nakajima et al., 2009).

Propolis diketahui memiliki aktivitas anti kanker. Mekanisme anti kanker propolis salah satunya adalah melalui induksi apoptosis, juga melalui penghambatan proliferasi dalam siklus sel. (Reed, 2000; Chen et al., 1996).

Homeostasis sel diatur oleh berbagai mekanisme yang berbeda, meliputi proliferasi, growth arrest, dan apoptosis (Story et al., 1998). Gangguan keseimbangan antara pertumbuhan dan kematian sel mengarah ke karsinogenesis. Proliferasi diatur oleh siklus sel, yang melibatkan rangkaian pertumbuhan dan replikasi sel (Foster, 2008).
Penggunaan propolis sebagai terapi penyakit baik penunjang maupun standar dimungkinkan karena propolis memiliki sejumlah aktivitas biologis antara lain antimikrobial, antifungal, antiprotozoa, antiparasit, antiinflamasi, antioksidan, dan imunomodulator (Orsi et al., 2000; Raso et al., 2001; Koo et al., 2002; Ahn et al., 2004; Lotfy, 2006; Nakajima et al., 2009; Mot et al., 2009; El-Bassuony dan Abouzid, 2010; Zaeemzadeh et al., 2011). Mekanisme anti kanker propolis salah satunya adalah melalui induksi apoptosis (Reed, 2000), Efek antikanker propolis salah satunya dari kemampuan menginisiasi apoptosis dari sel kanker (Shimizu et al., 1999). Mekanisme apoptosis dapat melalui dua jalur utama, jalur ekstrinsik, dan jalur intrinsik. Apoptosis jalur intrinsik diregulasi oleh sekelompok protein. Apoptosis merupakan mekanisme untuk mengontrol proliferasi sel (Ghobrial et al., 2005).

Apoptosis adalah proses kematian sel terprogram, merupakan salah satu mekanisme penting kematian sel dari terapi kanker, proses ini sangat penting ketika ada sel-sel yang berbahaya bagi suatu organisme. Dengan cara ini organisme dapat menghancurkan sel-sel yang membahayakan homeostasis, keganasan, mutasi, sel-sel yang mengabaikan sinyal dari regulasi siklus sel, kehilangan kemampuan untuk apoptosis, dan tidak dapat komunikasi dengan sel sekitar. Proses kematian sel terprogram ini bila terhambat, sel-sel tumor dapat mentoleransi sinyal apoptosis. Defek apoptosis diketahui sebagai faktor fundamental dalam pengembangan dan perkembangan kanker. Perbaikan dari respons terhadap apoptosis dapat menjadi terapi antitumor didasarkan kematian selektif sel kanker. (Evan dan Vousden, 2001; Johnstone et al., 2002).

Caspase 8 memiliki peran kunci sebagai regulator apoptosis, inaktivasi caspase 8 dapat mengakibatkan resistensi terhadap kematian sel. Genetik, epigenetik serta perubahan posttranslational dapat berkontribusi dalam 
inaktivasi caspase 8 pada keganasan di manusia. (Fulda dan Debatin, 2006).

Caspase-8 adalah caspase apikal yang memulai kematian sel terprogram dari ikatan dengan death receptor. Peran sentralnya dalam apoptosis memacu ketertarikan klinis dalam meregulasi ekspresi caspase-8 dan aktivitas proteolitik. Caspase 8 juga telah ditemukan untuk memiliki peran non-apoptosis pada sel, seperti mempromosikan aktivasi NFkB signaling, mengatur autophagy dan perubahan endosomal trafficking, serta meningkatkan adhesi dan migrasi selular. Sehingga, caspase-8 dapat mempotensiasi atau menekan keganasan (Stupack, 2013).

Terapi kanker kolorektal berbasis 5-fluorouracil (5-FU), menjadi gold standar selama lebih dari lima dekade, agen kemoterapi dengan target thymidylate synthetase, suatu gen penting yang dibutuhkan untuk proliferasi sel. Selain 5-FU, pilihan terapi saat ini disetujui untuk pengobatan kanker kolorektal terbatas, di antaranya irinotecan, oxaliplatin, dan targetted therapy seperti Cetuximab/Panitumumab, Bevacizumab dan Regorafenib. Ketika digunakan sebagai agen tunggal, respons terapi 5-FU di bawah 30\% (Bazzoco et al., 2015). Sampai saat ini 5-FU masih menjadi salah satu terapi kanker kolorektal dalam bentuk kombinasi dengan obat lain (Benson et al., 2015). Sehingga ada kebutuhan yang mendesak dalam perbaikan manajemen klinis pasien karsinoma kolorektal.

\section{METODE PENELITIAN}

Penelitian ini dilakukan secara in vitro, merupakan penelitian experimental laboratories, post test with control group design. Penelitian dilakukan pada kultur sel WiDr (kultur sel adenokarsinoma kolon) dengan perlakuan pemberian dosis ekstrak ethanol propolis, kontrol positif (5-FU), kombinasi ekstrak ethanol propolis dengan 5-FU, dan kontrol negatif (tanpa obat).

Pengamatan ekspresi protein Caspase 8 dilakukan dengan metode imunositokimia, pengamatan proliferasi menggunakan MTT assay dengan doubling time, sedangkan pengamatan apoptosis dilakukan dengan double staining menggunakan pewarnaan akridin oranye-etidium bromida.

\section{HASIL DAN PEMBAHASAN}

1. Uji sitotoksisitas dengan MTTassay untuk menetapkan nilai IC $_{50}$ ekstrak etanol propolis dan 5-Fluorouracil.

Sel WiDr ditumbuhkan pada media komplet, selanjutnya diberikan perlakuan dengan ekstrak etanol propolis. Sel WiDr yang hidup memiliki morfologi berbentuk poligonal dan menempel pada dasar sumuran, sedangkan sel WiDr yang mati bentuknya menjadi bulat dan lebih kecil dari sel hidup, tersebar dan tidak menempel pada dasar sumuran. Morfologi sel $\mathrm{WiDr}$ ditunjukkan pada Gambar 1.

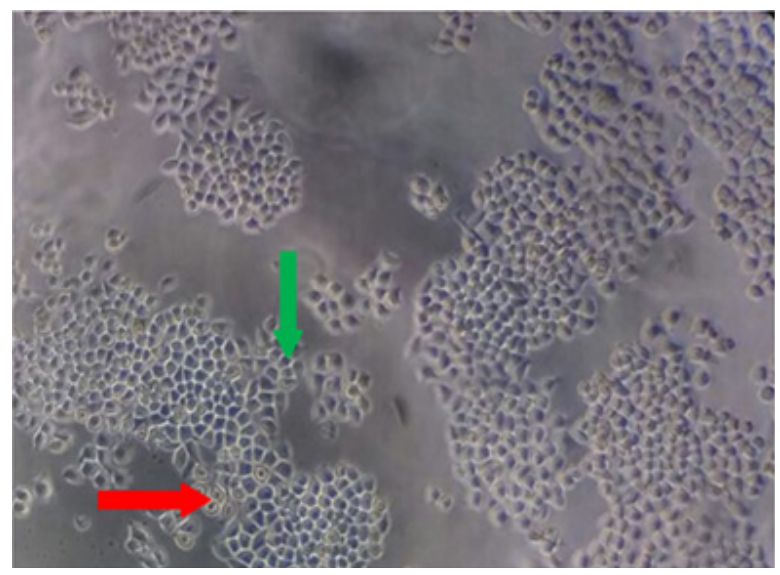

Gambar 1 Morfologi sel WiDr, sel hidup ditunjukkan panah warna hijau dan sel mati ditunjukkan panah warna merah. Sel diamati dengan mikroskop inverted dengan perbesaran 100 kali

Data yang didapatkan dari uji sitotoksisitas dengan MTT assay berupa absorbansi dari tiap sumuran yang merupakan hasil pembacaan dengan ELISA reader pada panjang gelombang $595 \mathrm{~nm}$. Untuk mendapatkan persentase viabilitas sel, data tersebut kemudian diolah lebih lanjut dengan cara membandingkan nilai absorbansi antara sel yang diberi perlakuan dan kontrol (sel tanpa perlakuan) setelah masing-masing dikurangi dengan kontrol media (blank). Data tersebut digunakan untuk menetapkan nilai IC50 bahan uji dengan menggunakan analisis regresi linear antara dosis bahan uji dan persentase viabilitas sel WiDr. Nilai rata-rata persentase viabilitas sel WiDr dan IC50 dari bahan uji ditunjukkan pada Tabel 1 . 
Tabel 1 Nilai rata-rata persentase viabilitas sel $\mathrm{WiDr}$ dan nilai $\mathrm{IC}_{50}$ bahan uji dengan metode MTT assay.

\begin{tabular}{cccc}
\hline Bahan Uji & $\begin{array}{c}\text { Konsentrasi } \\
(\mu \mathrm{g} / \mathrm{mL})\end{array}$ & $\begin{array}{c}\text { Rata-rata } \\
\text { viabilitas } \\
\text { sel } \mathrm{WiDr} \\
(\% \pm \mathrm{SD})\end{array}$ & $\begin{array}{c}\mathrm{IC}_{50} \pm \mathrm{SD} \\
(\mu \mathrm{g} / \mathrm{mL})\end{array}$ \\
\hline & 12,5 & $126,60 \pm 7,92$ & \\
Ekstrak Etanol & 25 & $103,93 \pm 7,23$ & \\
Propolis (EEP) & 50 & $67,78 \pm 1,63$ & $139,61 \pm 49,48$ \\
& 100 & $34,48 \pm 2,10$ & \\
& 200 & $15,31 \pm 1,75$ & \\
& 12,5 & $118,57 \pm 5,57$ & \\
5-Fluorouracil & 25 & $114,17 \pm 3,83$ & \\
(5-FU) & 50 & $112,61 \pm 6,86$ & $502,33 \pm 60,52$ \\
& 100 & $105,37 \pm 3,09$ & \\
& 200 & $91,27 \pm 4,86$ & \\
\hline
\end{tabular}

Tabel 1 Menunjukkan bahwa secara umum peningkatan konsentrasi EEP mengakibatkan penurunan persentase viabilitas sel WiDr. Pada konsentrasi EEP yang tertinggi $(200 \mu \mathrm{g} / \mathrm{mL})$, diperoleh persentase viabilitas sel $\mathrm{WiDr}$ yang terendah $(15,31 \%)$. Pada pemberian 5-FU secara umum tidak seefektif pemberian EEP, karena pada konsentrasi yang tertinggi $(200 \mu \mathrm{g} / \mathrm{uL})$ persentase viabilitas sel $\mathrm{WiDr}$ masih mencapai 91,27\%.

Dari analisis regresi linear diperoleh $\mathrm{IC}_{50}$ EEP sebesar $139,61 \mu \mathrm{g} / \mathrm{mL}$. Nilai $\mathrm{IC}_{50}$ EEP ini digunakan sebagai dasar penentuan konsentrasi EEP yang digunakan pada penelitian selanjutnya, yaitu sebesar 70, 140, dan $280 \mu \mathrm{g} / \mathrm{mL}\left(1 / 2 \mathrm{IC}_{50} \mathrm{IC}_{50}\right.$, dan $2 \mathrm{IC}_{50}$ ). Nilai $\mathrm{IC}_{50} 5$-FU yaitu sebesar 502,33 $\mu \mathrm{g} / \mathrm{mL}$ akan digunakan sebagai pembanding (kontrol positif).

\section{Pengamatan ekspresi protein Caspase 8}

Protein Caspase 8 adalah caspase inisiator langsung apoptosis jalur ekstrinsik dan tidak langsung pada jalur intrinsik. Ekspresi protein Caspase 8 ditunjukkan dengan warna coklat pada inti sel dan atau sitoplasma dengan bantuan mikroskop cahaya pembesaran 400x. Hal ini berdasarkan penelitian De Falco et al, pada tahun 2004 yang menyatakan bahwa ekspresi Caspase 8 bisa dijumpai pada inti dan sitoplasma sel yang sedang aktif membelah. Warna biru pada inti sel maupun sitoplasma menunjukkan tidak adanya ekspresi Caspase 8 pada sel atau level ekspresi yang rendah sehingga tidak terdeteksi. Ekspresi Caspase 8 dinilai sebagai persentase dari keseluruhan sel pada 5 lapangan pandang dan penilaiannya dilakukan pada replikasi $2 \mathrm{x}$ dari tiaptiap kelompok perlakuan. Satuan ukur \% dengan skala rasio.

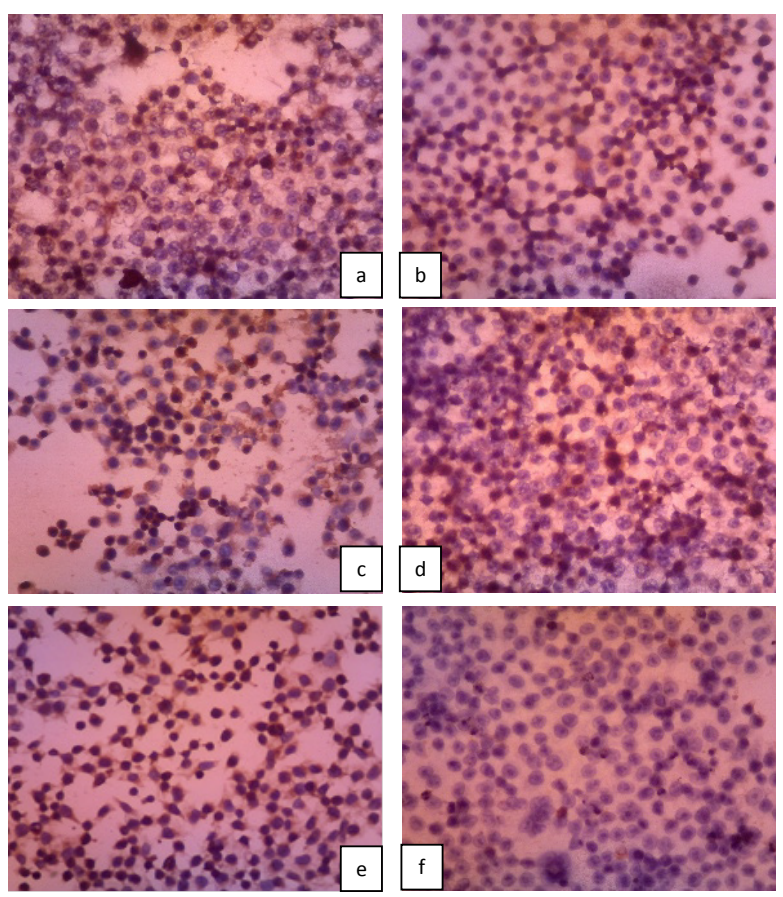

Gambar 2 Hasil pengecatan imunositokimia perbesaran 400 kali untuk ekspresi caspase 8 pada sel WiDr setelah perlakuan dan inkubasi selama 24 jam pada kelompok dengan EEP konsentrasi 1 12 IC50 (a), IC50 (b), 2IC50 (c), kelompok dengan 5-FU (d) kelompok IC50 EEP + 5-FU dan kelompok kontrol (f). Sel yang mengekspresikan Caspase 8 ditunjukkan dengan panah warna merah

Tabel 2 Hasil pengujian (ANOVA) variabel ekspresi caspase 8 menurut kelompok sampel

\begin{tabular}{|l|l|c|c|c|}
\hline \multicolumn{2}{|c|}{ Kelompok } & \multirow{2}{*}{ Mean \pm SD } & \multicolumn{2}{|c|}{ ANOVA (Uji F) } \\
\cline { 3 - 3 } & & Stat-F & Sig \\
\hline \multirow{4}{*}{ Caspase 8 } & Kontrol & $7,70 \pm 2,30$ & & \\
\cline { 2 - 3 } & $1 / 2$ IC50EEP & $29,32 \pm 2,70$ & & \\
\cline { 2 - 3 } & IC50EEP & $37,65 \pm 4,07$ & \multirow{2}{*}{60,78} & \multirow{2}{*}{$0,001^{* * *}$} \\
\cline { 2 - 3 } & 2IC50EEO & $64,21 \pm 18,03$ & & \\
\cline { 2 - 3 } & IC505FU & $37,07 \pm 3,19$ & & \\
\cline { 2 - 3 } & IC505FU+EEP & $66,13 \pm 10,82$ & & \\
& & & & \\
\end{tabular}

Hasil analisis variasi atau beda 6 mean di atas menunjukkan bahwa perbedaan 6 mean variabel Ekspresi Caspase 8 menghasilkan nilai $\mathrm{F}$ hitung $=60,78$ dengan tingkat signifikansi sebesar 0,001 yang berarti beda 6 mean itu signifikan atau meyakinkan dengan derajat signifikansi sebesar 5 persen $(\mathrm{p}<0,05)$. 
Tabel 3 Penelusuran beda dua mean variabel ekspresi caspase 8 antar kelompok sampel

\begin{tabular}{|l|c|c|}
\hline \multicolumn{1}{|c|}{ Penelusuran Beda 2 Mean } & Beda Mean & Signifikansi \\
\hline k-Kontrol - k-1/2IC50EEP & $-21,62$ & $0,001^{* *}$ \\
\hline k-Kontrol - k-1IC50EEP & $-29,95$ & $0,001^{* *}$ \\
\hline k-Kontrol - k-2IC50EEP & $-56,51$ & $0,001^{* *}$ \\
\hline k-Kontrol - k-IC505FU & $-29,37$ & $0,001^{* *}$ \\
\hline k-Kontrol - k-IC505FU+EEP & $-58,43$ & $0,001^{* *}$ \\
\hline k-1/2IC50EEP - k-1IC50EEP & $-8,34$ & 0,313 \\
\hline k-1/2IC50EEP - k-2IC50EEP & $-34,89$ & $0,001^{* *}$ \\
\hline k-1/2IC50EEP - k-IC505FU & $-7,76$ & 0,392 \\
\hline k-1/2IC50EEP - k-IC505FU+EEP & $-36,81$ & $0,001^{* *}$ \\
\hline k-1IC50EEP - k-2IC50EEP & $-26,56$ & $0,001^{* *}$ \\
\hline k-1IC50EEP - k-IC505FU & 0,58 & 1,000 \\
\hline k-1IC50EEP - k-IC505FU+EEP & $-28,47$ & $0,001^{* *}$ \\
\hline k-2IC50EEP - k-IC505FU & 27,14 & $0,001^{* *}$ \\
\hline k-2IC50EEP - k-IC505FU+EEP & $-1,91$ & 0,997 \\
\hline k-IC505FU - k-IC505FU+EEP & $-29,06$ & $0,001^{* *}$ \\
\hline
\end{tabular}

Hasil analisis beda 2 mean sampel independen menggunakan penelusuran Post Hoc Test Turkey di atas menunjukkan bahwa uji terhadap variabel ekspresi Caspase 8 antara kelompok kontrol dan kelompok perlakuan EEP baik k-1/2IC50EEP,k-1IC50EEP, dan k-2IC50EEP semua signifikan pada derajat signifikansi 5 persen $(p<0,05)$. Semua perlakuan pemberian EEP dapat menjadikan rata-rata ekspresi Caspase 8 lebih tinggi secara meyakinkan.

Pengaruh EEP dapat meningkatkan rata-rata ekspresi Caspase 8 itu sama pada k-1/2IC50 EEP, k-1IC50 EEP dan k-IC505-FU, karena terbukti rata-rata ekspresi Caspase 8 antar masing-masing dari 3 kelompok itu menunjukkan tidak berbeda secara signifikan pada derajat signifikansi 5 persen $(\mathrm{p}>0,05)$.

\section{Uji apoptosis EEP pada sel WiDr dengan double staining}

Setelah inkubasi selama 24 jam, dilakukan uji apoptosis dengan metode double staining menggunakan pewarnaan akridin oranye-etidium bromida, dan tiap-tiap kelompok perlakuan dibuat duplo. Data yang diperoleh berupa persentase sel WiDr yang hidup, mengalami apoptosis, maupun nekrosis pada keenam kelompok perlakuan.

Hasil analisis variasi atau beda 6 mean di atas menunjukkan bahwa perbedaan 6 mean variabel Apoptosis menghasilkan nilai $\mathrm{F}$ hitung
$=29,02$ dengan tingkat signifikansi sebesar 0,001 yang berarti beda 6 mean itu signifikan atau meyakinkan dengan derajat signifikansi sebesar 5 persen $(\mathrm{p}<0,05)$. Hal itu berarti beda mean variabel Apoptosis pada k-kontrol, k-1/2IC50EEP, k-1IC50EEP, k-1IC50EEP, k-IC505FU, dan k-IC505FU+EEP benar-benar berbeda secara meyakinkan.
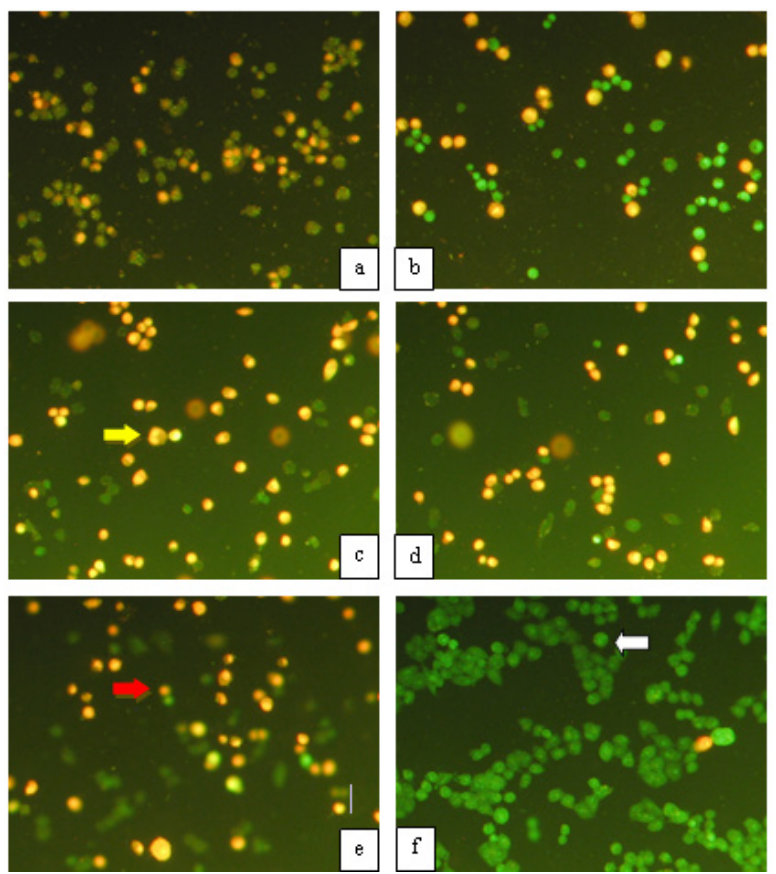

Gambar 4 Hasil double staining sel WiDr setelah perlakuan dan inkubasi selama 24 jam pada kelompok dengan EEP konsentrasi $1 \frac{1}{2}$ IC50 (a), IC50 (b), 2IC50

(c), kelompok dengan 5-FU (d) kelompok IC50

EEP + 5-FU dan kelompok kontrol (f). panah putih menunjukkan sel hidup, panah kuning apoptosis, dan panah merah nekrosis

Tabel 4 Hasil pengujian (ANOVA) variabel apoptosis menurut kelompok sampel

\begin{tabular}{|c|c|c|c|c|}
\hline \multirow{2}{*}{\multicolumn{2}{|c|}{ Kelompok }} & \multirow{2}{*}{ Mean \pm SD } & \multicolumn{2}{|c|}{ Uji Normalitas } \\
\hline & & & Stat-SW & Sig \\
\hline \multirow{6}{*}{ Apoptosis } & Kontrol & $0.64 \pm 0.18$ & \multirow{6}{*}{29,02} & \multirow{6}{*}{$0,001 * *$} \\
\hline & 1/2IC50EEP & $37.16 \pm 8.76$ & & \\
\hline & IC50EEP & $53.16 \pm 5.64$ & & \\
\hline & 2IC50EEO & $70.10 \pm 16.25$ & & \\
\hline & IC505FU & $68.47 \pm 4.75$ & & \\
\hline & IC505FU+EEP & $58.98 \pm 13,02$ & & \\
\hline
\end{tabular}

Hasil analisis variasi atau beda 6 mean di atas menunjukkan bahwa perbedaan 6 mean variabel apoptosis menghasilkan nilai $\mathrm{F}$ hitung = 
29,02 dengan tingkat signifikansi sebesar 0,001 yang berarti beda 6 mean itu signifikan atau meyakinkan dengan derajat signifikansi sebesar 5 persen $(\mathrm{p}<0,05)$. Hal itu berarti beda mean variabel Apoptosis pada k-kontrol, k-1/2IC50EEP, k-1IC50EEP, k-1IC50EEP, k-IC505FU, dan k-IC505FU+EEP benar-benar berbeda secara meyakinkan.

Tabel 5 Penelusuran beda dua mean variabel apoptosis antar kelompok sampel

\begin{tabular}{|c|c|c|}
\hline Penelusuran Beda 2 Mean & Beda Mean & Signifikansi \\
\hline $\mathrm{k}$-Kontrol - k-1/2IC50EEP & $-36,52$ & $0,001 * *$ \\
\hline k-Kontrol - k-1IC50EEP & $-52,51$ & $0,001 * *$ \\
\hline $\mathrm{k}$-Kontrol - k-2IC50EEP & $-69,46$ & $0,001 * *$ \\
\hline k-Kontrol - k-IC505FU & $-67,83$ & $0,001 * *$ \\
\hline k-Kontrol - k-IC505FU+EEP & $-58,34$ & $0,001 * *$ \\
\hline $\mathrm{k}-1 / 2 \mathrm{IC} 50 \mathrm{EEP}-\mathrm{k}-1 \mathrm{IC} 50 \mathrm{EEP}$ & $-16,00$ & 0,232 \\
\hline $\mathrm{k}-1 / 2 \mathrm{IC} 50 \mathrm{EEP}-\mathrm{k}-2 \mathrm{IC} 50 \mathrm{EEP}$ & $-32,94$ & $0,002 * *$ \\
\hline $\mathrm{k}-1 / 2 \mathrm{IC} 50 \mathrm{EEP}-\mathrm{k}-\mathrm{IC} 505 \mathrm{FU}$ & $-31,31$ & $0,003 * *$ \\
\hline $\mathrm{k}-1 / 2 \mathrm{IC} 50 \mathrm{EEP}-\mathrm{k}$-IC505FU+EEP & $-21,82$ & 0,050 \\
\hline $\mathrm{k}-1 \mathrm{IC} 50 \mathrm{EEP}-\mathrm{k}-2 \mathrm{IC} 50 \mathrm{EEP}$ & $-16,95$ & 0,185 \\
\hline k-1IC50EEP - k-IC505FU & \multicolumn{2}{|c|}{$\begin{array}{l}-15, \text { Series "Kontrol" Point "21C5 } \\
\text { value: } 70,10\end{array}$} \\
\hline $\mathrm{k}-1 \mathrm{IC} 50 \mathrm{EEP}-\mathrm{k}-\mathrm{IC} 505 \mathrm{FU}+\mathrm{EEP}$ & $-5,82$ & 0,954 \\
\hline $\mathrm{k}-2 \mathrm{IC} 50 \mathrm{EEP}-\mathrm{k}-\mathrm{IC} 505 \mathrm{FU}$ & 1,63 & 1,000 \\
\hline $\mathrm{k}-2 \mathrm{IC} 50 \mathrm{EEP}-\mathrm{k}-\mathrm{IC} 505 \mathrm{FU}+\mathrm{EEP}$ & 11,13 & 0,596 \\
\hline $\mathrm{k}$-IC505FU - k-IC505FU+EEP & 9,49 & 0,736 \\
\hline
\end{tabular}

Hasil analisis beda 2 mean sampel independen menggunakan penelusuran Post Hoc Test Turkey di atas menunjukkan bahwa uji terhadap variabel Apoptosis antara kelompok kontrol dan kelompok perlakuan EEP baik k-1/2IC50EEP, k-1IC50EEP, dan k-2IC50EEP semua signifikan pada derajat signifikansi 5 persen $(p<0,05)$. Semua perlakuan pemberian EEP dapat menjadikan rata-rata Apoptosis meningkat lebih tinggi secara meyakinkan.

Pengaruh EEP dapat meningkatkan ratarata Apoptosis itu sama pada k-1/2IC50EEP dan k-1IC50EEP, karena terbukti rata-rata apoptosis kedua kelompok itu menunjukkan tidak berbeda secara signifikan pada derajat signifikansi 5 persen $(\mathrm{p}>0,05)$. Namun demikian rata-rata apoptosis pada k-1/2IC50EEP dan 2IC50EEP menunjukkan perbedaan yang sangat signifikan pada derajat signifikansi 5 persen $(\mathrm{p}<0,05)$. Sementara antara rata-rata apoptosis pada k-1IC50 EEP dan k-2IC50 EEP tidak perbeda secara meyakinkan pada derajat signifikansi 5 persen $(\mathrm{p}>0,05)$. Hal ini berarti EEP dapat menginduksi apoptosis pada semua level dosis yaitu 1/2IC50, 1IC50, dan 2IC50 namun dampak EEP pada ketiga level ini cenderung tidak berbeda secara meyakinkan.

\section{Pengamatan anti proliferasi eep menggunakan doubling time.}

Hasil pengujian ANOVA atau uji $F$ terhadap beda mean variabel proliferasi pada masing-masing kelompok sampel (6 kelompok) dijelaskan berdasarkan 3 (tiga) waktu pengamatan dan pengukuran yaitu pada waktu 24 jam (proliferasi-24), waktu 48 jam (proliferasi-48), dan waktu 72 jam (proliferasi-72).

Hasil proliferasi setelah inkubasi 24 jam:

Tabel 6 Hasil pengujian ANOVA variabel proliferasi-24 menurut kelompok sampel

\begin{tabular}{|c|c|c|c|c|}
\hline \multirow{2}{*}{\multicolumn{2}{|c|}{ Kelompok }} & \multirow{3}{*}{$\begin{array}{l}\text { Mean } \pm S D \\
0,08 \pm 0,003\end{array}$} & \multicolumn{2}{|c|}{ ANOVA (Uji F) } \\
\hline & & & Stat $\mathrm{F}$ & $\mathrm{Sin}$ \\
\hline \multirow{7}{*}{ Proliferasi-24 } & Kontrol-Media & & \multirow{7}{*}{569,14} & \multirow{7}{*}{$0,001^{* *}$} \\
\hline & Kontrol-Sel & $0,56 \pm 0,014$ & & \\
\hline & 1/2IC50EEP & $0,35 \pm 0,025$ & & \\
\hline & IC50EEP & $0,25 \pm 0,008$ & & \\
\hline & 2IC50EEP & $0,12 \pm 0,002$ & & \\
\hline & IC505FU & $0,53 \pm 0,028$ & & \\
\hline & IC505FU+EEP & $0,22 \pm 0,006$ & & \\
\hline
\end{tabular}

Hasil analisis variasi atau beda 7 mean di atas menunjukkan bahwa perbedaan 7 mean (ditambah dengan kelompok kontrol media) variabel Proliferasi-24 menghasilkan nilai F hitung $=569,14$ dengan tingkat signifikansi sebesar 0,001 yang berarti beda 7 mean itu signifikan atau meyakinkan dengan derajat signifikansi sebesar 5 persen $(\mathrm{p}<0,05)$. Hal itu berarti beda mean variabel Proliferasi-24 pada k-kontrol-media, k-kontrol-sel, k-1/2IC50EEP, k-1IC50EEP, k-1IC50EEP, k-IC505FU, dan k-IC505FU+EEP benar-benar berbeda secara meyakinkan.

Tabel 7 Penelusuran beda dua mean variabel proliferasi-24 antar kelompok sampel

\begin{tabular}{|l|c|c|}
\hline \multicolumn{1}{|c|}{ Penelusuran Beda 2 Mean } & Beda Mean & Signifikansi \\
\hline k-kontrol-media - k-kontrol-sel & $-0,268$ & $0,001^{* *}$ \\
\hline k-Kontrol sel-k-1/2IC50EEP & 0,216 & $0,001^{* *}$ \\
\hline k-Kontrol sel-k-1IC50EEP & 0,319 & $0,001^{* *}$ \\
\hline k-Kontrol sel-k-2IC50EEP & 0,443 & $0,001^{* *}$ \\
\hline
\end{tabular}




\begin{tabular}{|l|c|c|}
\hline k-Kontrol sel-k-IC505FU & 0,037 & $0,044^{*}$ \\
\hline k-Kontrol sel-k-IC505FU+EEP & 0,346 & $0,001^{* *}$ \\
\hline k-1/2IC50EEP-k-1IC50EEP & 0,103 & $0,001^{* *}$ \\
\hline k-1/2IC50EEP-k-2IC50EEP & 0,227 & $0,001^{* *}$ \\
\hline k-1/2IC50EEP-k-IC505FU & $-0,179$ & $0,001^{* *}$ \\
\hline k-1/2IC50EEP-k-IC505FU+EEP & 0,130 & $0,001^{* *}$ \\
\hline k-1IC50EEP-k-2IC50EEP & 0,124 & $0,001^{* *}$ \\
\hline k-1IC50EEP-k-IC505FU & $-0,282$ & $0,001^{* *}$ \\
\hline k-1IC50EEP-k-IC505FU+EEP & 0,027 & 0,233 \\
\hline k-2IC50EEP-k-IC505FU & $-0,406$ & $0,001^{* *}$ \\
\hline k-2IC50EEP-k-IC505FU+EEP & $-0,097$ & $0,001^{*}$ \\
\hline k-IC505FU-k-IC505FU+EEP & 0,309 & $0,001^{* *}$ \\
\hline
\end{tabular}

Hasil analisis beda 2 mean sampel independent dengan Post Hoc Test di atas menunjukkan bahwa variabel proliferasi-48 antara kelompok kontrol-sel dengan kelompok perlakuan pemberian EEP yaitu k-1/2IC50EEP, k-1IC50EEP dan k-2IC50EEP masing-masing berbeda secara signifikan pada derajat signifikansi 5 persen $(\mathrm{p}$ $<0,05)$. Hal itu menunjukkan bahwa dengan pemberian EEP dapat menekan proliferasi-48 pada ketiga kelompok perlakuan pemberian EEP itu. Jadi dengan pemberian EEP ada kecenderungan mampu menghambat proliferasi baik pada dosis 1/2IC50 dan 1IC50 maupun 2IC50. Dampak penekanan pada proliferasi akibat pemberian EEP pada 2IC50 (k-2IC50EEP) ternyata cenderung sama besar jika dibandingkan pada 1IC50 (k-1IC50EEP) maupun pada 1/2IC50 (k-1/2IC50EEP). Hal itu diperkuat dengan bukti bahwa perbedaan kedua mean (rata-rata) masingmasing tidak signifikan pada derajat signifikan 5 persen $(p>0,05)$.

Hasil proliferasi setelah inkubasi 48 jam:

Tabel 8 Hasil pengujian ANOVA variabel proliferasi-48 menurut kelompok sampel

\begin{tabular}{|c|l|c|c|c|}
\hline \multicolumn{2}{|c|}{ Kelompok } & \multirow{2}{*}{ Mean \pm SD } & \multicolumn{2}{|c|}{ ANOVA (Uji F) } \\
\cline { 2 - 3 } & & Stat-F & Sig \\
\hline \multirow{4}{*}{ Proliferasi-48 } & Kontrol-Media & $0,08 \pm 0,012$ & & \\
\cline { 2 - 3 } & Kontrol-Sel & $0,86 \pm 0,11$ & & \\
\cline { 2 - 3 } & $1 / 2$ IC50EEP & $0,12 \pm 0,014$ & & \\
\cline { 2 - 3 } & IC50EEP & $0,25 \pm 0,008$ & \multirow{3}{*}{196,51} & $0,001 * *$ \\
\cline { 2 - 3 } & 2IC50EEP & $0,12 \pm 0,002$ & & \\
\cline { 2 - 3 } & IC505FU & $0,15 \pm 0,009$ & & \\
\cline { 2 - 3 } & IC505FU+EEP & $0,10 \pm 0,003$ & & \\
\hline
\end{tabular}

Hasil analisis beda 2 mean sampel independent dengan Post Hoc Test di atas menunjukkan bahwa variabel Proliferasi-48 antara kelompok Kontrol-sel dengan kelompok perlakuan pemberian EEP yaitu k-1/2IC50EEP, k-1IC50EEP dan k-2IC50EEP masing-masing berbeda secara signifikan pada derajat signifikansi 5 persen $(\mathrm{p}<0,05)$. Hal itu menunjukkan bahwa dengan pemberian EEP dapat menekan Proliferasi-48 pada ketiga kelompok perlakuan pemberian EEP itu. Jadi dengan pemberian EEP ada kecenderungan mampu menghambat proliferasi baik pada dosis 1/2IC50 dan 1IC50 maupun 2IC50. Dampak penekanan pada proliferasi akibat pemberian EEP pada 2IC50 ( $\mathrm{k}$-2IC50EEP) ternyata cenderung sama besar jika dibandingkan pada 1IC50 (k-1IC50EEP) maupun pada 1/2IC50 (k-1/2IC50EEP). Hal itu diperkuat dengan bukti bahwa perbedaan kedua mean (ratarata) masing-masing tidak signifikan pada derajat signifikan 5 persen $(p>0,05)$.

Tabel 9 Penelusuran beda dua mean variabel proliferasi-48 antar kelompok sampel

\begin{tabular}{|l|c|c|}
\hline \multicolumn{1}{|c|}{ Penelusuran Beda 2 Mean } & Beda Mean & Signifikansi \\
\hline k-kontrol-media - k-kontrol-sel & $-0,784$ & $0,001^{* *}$ \\
\hline k-Kontrol sel-k-1/2IC50EEP & 0,741 & $0,001^{* *}$ \\
\hline k-Kontrol sel-k-1IC50EEP & 0,762 & $0,001^{* *}$ \\
\hline k-Kontrol sel-k-2IC50EEP & 0,768 & $0,001^{* *}$ \\
\hline k-Kontrol sel-k-IC505FU & 0,711 & $0,001^{* *}$ \\
\hline k-Kontrol sel-k-IC505FU+EEP & 0,761 & $0,001^{* *}$ \\
\hline k-1/2IC50EEP-k-1IC50EEP & 0,021 & 0,990 \\
\hline k-1/2IC50EEP-k-2IC50EEP & 0,027 & 0,965 \\
\hline k-1/2IC50EEP-k-IC505FU & $-0,031$ & 0,934 \\
\hline k-1/2IC50EEP-k-IC505FU+EEP & 0,020 & 0,991 \\
\hline k-1IC50EEP-k-2IC50EEP & 0,006 & 1,000 \\
\hline k-1IC50EEP-k-IC505FU & $-0,051$ & 0,582 \\
\hline k-1IC50EEP-k-IC505FU+EEP & $-0,001$ & 1,000 \\
\hline k-2IC50EEP-k-IC505FU & $-0,057$ & 0,457 \\
\hline k-2IC50EEP-k-IC505FU+EEP & $-0,006$ & 1,000 \\
\hline k-IC505FU - k-IC505FU+EEP & 0,051 & 0,587 \\
\hline
\end{tabular}

Hasil analisis beda 2 mean sampel independen dengan Post Hoc Test di atas menunjukkan bahwa variabel proliferasi-48 antara kelompok kontrol-sel dengan kelompok perlakuan pemberian EEP yaitu k-1/2IC50EEP, k-1IC50EEP dan k-2IC50EEP masing-masing berbeda secara 
signifikan pada derajat signifikansi 5 persen (p $<0,05$ ). Hal itu menunjukkan bahwa dengan pemberian EEP dapat menekan proliferasi-48 pada ketiga kelompok perlakuan pemberian EEP itu. Jadi dengan pemberian EEP ada kecenderungan mampu menghambat proliferasi baik pada dosis 1/2IC50 dan 1IC50 maupun 2IC50. Dampak penekanan pada proliferasi akibat pemberian EEP pada 2IC50 (k-2IC50EEP) ternyata cenderung sama besar jika dibandingkan pada 1IC50 (k-1IC50EEP) maupun pada 1/2IC50 (k-1/2IC50EEP). Hal itu diperkuat dengan bukti bahwa perbedaan kedua mean (rata-rata) masingmasing tidak signifikan pada derajat signifikan 5 persen $(p>0,05)$.

Hasil proliferasi setelah inkubasi 48 jam:

Tabel 10 Hasil pengujian ANOVA variabel proliferasi-72 menurut kelompok sampel

\begin{tabular}{|c|c|c|c|c|}
\hline \multirow{2}{*}{\multicolumn{2}{|c|}{ Kelompok }} & \multirow{2}{*}{ Mean $\pm S D$} & \multicolumn{2}{|c|}{ ANOVA (Uji F) } \\
\hline & & & Stat-F & $\mathrm{Sig}$ \\
\hline \multirow{7}{*}{ Proliferasi- 72} & Kontrol-Media & $0,08 \pm 0,003$ & \multirow{7}{*}{$1.565,08$} & \multirow{7}{*}{$0,001^{* *}$} \\
\hline & Kontrol-Sel & $1,10 \pm 0,046$ & & \\
\hline & 1/2IC50EEP & $0,13 \pm 0,007$ & & \\
\hline & IC50EEP & $0,09 \pm 0,008$ & & \\
\hline & 2IC50EEP & $0,10 \pm 0,007$ & & \\
\hline & IC505FU & $0,10 \pm 0,012$ & & \\
\hline & IC505FU+EEP & $0,10 \pm 0,012$ & & \\
\hline
\end{tabular}

Hasil analisis variasi atau beda 7 mean di atas menunjukkan bahwa perbedaan 7 mean (ditambah dengan kelompok kontrol media) variabel proliferasi-72 menghasilkan nilai $\mathrm{F}$ hitung= 1.565,08 dengan tingkat signifikansi sebesar 0,001 yang berarti beda 7 mean itu signifikan atau meyakinkan dengan derajat signifikansi sebesar 5 persen $(p<0,05)$.

Tabel 11 Penelusuran beda dua mean variabel proliferasi-72 antar kelompok sampel

\begin{tabular}{|l|c|c|}
\hline \multicolumn{1}{|c|}{ Penelusuran Beda 2 Mean } & Beda Mean & Signifikansi \\
\hline k-kontrol-media - k-kontrol-sel & $-1,018$ & $0,001^{* *}$ \\
\hline k-Kontrol sel-k-1/2IC50EEP & 0,973 & $0,001^{* *}$ \\
\hline k-Kontrol sel-k-1IC50EEP & 1,008 & $0,001^{* *}$ \\
\hline k-Kontrol sel-k-2IC50EEP & 0,997 & $0,001^{* *}$ \\
\hline k-Kontrol sel-k-IC505FU & 0,999 & $0,001^{* *}$ \\
\hline k-Kontrol sel-k-IC505FU+EEP & 0,997 & $0,001^{* *}$ \\
\hline k-1/2IC50EEP-k-1IC50EEP & 0,035 & 0,172 \\
\hline k-1/2IC50EEP-k-2IC50EEP & 0,024 & 0,576 \\
\hline
\end{tabular}

\begin{tabular}{|l|c|c|}
\hline$k-1 / 2$ IC50EEP-k-IC505FU & 0,026 & 0,486 \\
\hline$k-1 / 2$ IC50EEP-k-IC505FU+EEP & 0,024 & 0,564 \\
\hline$k$-1IC50EEP-k-2IC50EEP & $-0,011$ & 0,978 \\
\hline$k-1$ IC50EEP-k-IC505FU & $-0,009$ & 0,992 \\
\hline$k-1$ IC50EEP-k-IC505FU+EEP & $-0,011$ & 0,981 \\
\hline$k-2 I C 50 E E P-k-I C 505 F U$ & 0,002 & 1,000 \\
\hline$k-2 I C 50 E E P-k-I C 505 F U+E E P$ & 0,001 & 1,000 \\
\hline$k-I C 505 F U-k-I C 505 F U+E E P$ & $-0,002$ & 1,000 \\
\hline
\end{tabular}

Hasil analisis beda 2 mean sampel independent dengan Post Hoc Test di atas menunjukkan bahwa variabel proliferasi-72 antara kelompok kontrol-sel dengan kelompok perlakuan pemberian EEP yaitu k-1/2IC50EEP, k-1IC50EEP dan k-2IC50EEP masing-masing berbeda secara signifikan pada derajat signifikansi 5 persen $(\mathrm{p}<0,05)$. Hal itu menunjukkan bahwa dengan pemberian EEP dapat menekan proliferasi 72 pada ketiga kelompok perlakuan pemberian EEP itu. Jadi dengan pemberian EEP ada kecenderungan mampu menghambat proliferasi baik pada dosis 1/2IC50 dan 1IC50 maupun 2IC50. Dampak penekanan pada proliferasi akibat pemberian EEP pada 2IC50 (k-2IC50EEP) ternyata cenderung sama besar jika dibandingkan pada 1IC50 (k-1IC50EEP) maupun pada 1/2IC50 (k-1/2IC50EEP). Hal itu diperkuat dengan bukti bahwa perbedaan kedua mean (rata-rata) masingmasing tidak signifikan pada derajat signifikan 5 persen $(p>0,05)$.

Penelitian ini bertujuan untuk mengkaji pengaruh pemberian ekstrak propolis terhadap ekspresi Caspase 8, Proliferasi dan Apoptosis pada kultur sel WiDr.

Uji sitotoksisitas dilakukan untuk menetapkan nilai IC50 senyawa EEP dan 5-FU yang selanjutnya akan digunakan sebagai dasar penetapan konsentrasi EEP dan 5-FU untuk pengamatan pada masing-masing variabel. Aktivitas sitotoksisitas EEP pada sel WiDr setelah inkubasi 24 jam dinyatakan dengan nilai IC50 yang diperoleh melalui analisis regresi linear. Pada analisis tersebut diperoleh IC50 EEP pada sel WiDr di penelitian ini sebesar 139,32 ug/mL. EEP diberikan dalam 3 dosis, 1/2 IC50, 1 IC50, dan 2 IC50.

Pada uji sitotoksisitas ini secara umum didapatkan persentase viabilitas sel WiDr menurun sebanding dengan peningkatan konsentrasi EEP 
yang diberikan. Hal ini menunjukkan bahwa pemberian EEP konsentrasi 70-280 ug/mL selama 24 jam mampu menurunkan viabilitas dan menghambat proliferasi sel WiDr.

Hasil ini sejalan dengan beberapa penelitian eksperimen in vitro bahwa propolis mempunyai efek sitotoksik, antiproliferatif, dan induksi apoptosis pada berbagai sel kanker (Kubina et al, 2015).

Induksi apoptosis sel WiDr oleh EEP pada penelitian ini kemungkinan terkait dengan kemampuan EEP dalam meningkatkan ekpresi protein Caspase 8 ada sel WiDr (Backus, et al., 2003).

Efek anti proliferatif EEP diduga dari penghambatan WNT (The wingless-type glycoprotein) signaling pathway. WNT signaling pathway berperan dalam 90\% kasus kanker kolorektal. CAPE, suatu kandungan aktif dari propolis dosis 2,5-80 $\mathrm{mg} / \mathrm{l}$ diketahui menghambat proliferasi sel kolorektal cell line SW480 dengan menekan ekspresi b-katenin dan cyclin D1 serta ekpresi protein c-myc. (He et al., 2006).

\section{SIMPULAN}

Berdasarkan hasil penelitian, didapatkan kesimpulan sebagai berikut:

1. Ada pengaruh pemberian ekstrak ethanol propolis konsentrasi 70, 140 dan $280 \mu \mathrm{g} /$ $\mathrm{mL}$ terhadap peningkatan ekspresi protein Caspase 8 pada kultur sel WiDr.

2. Ada pengaruh pemberian ekstrak ethanol propolis konsentrasi $70,140 \mathrm{dan} 280 \mu \mathrm{g} / \mathrm{mL}$ terhadap apoptosis pada kultur sel WiDr.

3. Ada pengaruh pemberian ekstrak ethanol propolis konsentrasi 70,140 dan $280 \mu \mathrm{g} / \mathrm{mL}$ terhadap proliferasi pada kultur sel WiDr.

\section{DAFTAR PUSTAKA}

Ahn, M.R., Kumazawa, S., Hamasaka, T., Bang, K.S., Nakayama, T. 2004. Antioxidant Activity and Constituents of Propolis Collected in Various Areas of Korea. Journal of Agricultural and Food Chemistry, 52(24):p.7286-92.

Backus HH, Wouters D, Ferreira CG, Van Houten VM, Brakenhoff RH, Pinedo HM, et al. 2003. Thymidylate Synthase Inhibition Triggers Apoptosis via Caspases-8 and -9 in Both Wild-Type and Mutant p53 Colon Cancer Cell Lines. European Journal of Cancer 39. 1310-7.

Bazzocco S, Dopeso H, Carton-Garcia F, Macaya I, Andretta E, Chionh F. 2015. Highly Expressed Genes in Rapidly Proliferating Tumor Cells as New Targets for Colorectal Cancer Treatment. Clin Cancer Res. 15; 21 (16): 3695-704.

Benson AI, Venook AP, Bekaii Saab T, Chan E, Chen YJ, Cooper HS. 2015. Colon Cancer. National Comprehensive Cancer Network, Inc. Guideline.

Chen, J.H., Shao, Y., Huang, M.T., Chin, C.K., Ho, C.T. 1996. Inhibitory Effect of Caffeic Acid Phenethyl Ester on Human Leukemia HL-60 Cells. Cancer Lett. 108:211-214.

Evan GI dan Vousden KH. 2001. Proliferation, Cell Cycle and Apoptosis in Cancer. Nature 411: $342-$ 348.

El-Bassuony A, AbouZid S, 2010. A New Prenylated Flavanoid with Antibacterial Activity from Propolis Collected in Egypt. Natural Product Communications, 5(1):p.43-5.

Ferlay J, Soerjomataram I, Dikshit R, Eser S, Mathers C, Rebelo M, et al. 2015. Cancer Incidence and Mortality Worldwide: Sources, Methods and Major Patterns in GLOBOCAN 2012. Int. J. Cancer: 136, E359-86.

Foster I. 2008. Cancer: A Cell Cycle Defect. Radiography. 14: 144-149.

Frozza DS, Garcia C, Gambato G, de Souza O, Salvador M, Moura S, et al. 2013. Chemical Characterization, Antioxidant, and Cytotoxic Activities of Brazilian Red Propolis. Food Chem Toxicol, 52: 137-142.

Fulda S, Debatin KM. 2006. Extrinsic Versus Intrinsic Apoptosis Pathways in Anticancer Chemotherapy. Oncogene. 7; 25 (34):4798-811 
Ghobrial IM, Witzig TE, Adjei AA. 2005. Targeting Apoptosis Pathways in Cancer Therapy. CA Cancer J Clin, 55(3):178-94.

He YJ, Liu BH, Xiang DB, Qiao ZY, Fu T, He YH. 2006. Inhibitory Effect of Caffeic Acid Phenethyl Ester on the Growth of SW480 Colorectal Tumor Cells Involves b-catenin Associated Signaling Pathway Down-regulation. World J Gastroenterol.12:4981-4985.

Johnstone RW, Ruefli AA dan Lowe SW. 2002. Apoptosis: a Link between Cancer Genetics and Chemotherapy. Cell 108: 153-164.

Koo H, Rosalen PL, Cury JA, Park YK, Bowen WH. 2002. Effects of Compounds Found in Propolis on Streptococcus mutans Growth and on Glucosyltransferase Activity. Antimicrobial Agents and Chemotherapy, p.1302-9.

Kubina, R., Dzik, A.K., Dziedzic, A., Bielec, B., Wojtczka, R.D., Buldok, R.J., Wysznynska, M., et al. 2015. The Ethanol Extract of Polish Propolis Exhibits Anti-proliferative and/or Pro-apoptotic Effect on HCT 116 Colon Cancer and Me45 Malignant Melanoma Cell in Vitro Conditions. Adv Clin Exp Med. 24(2): 203-212.

Lotfy M, 2006. Biological Activity of Bee Propolis in Health and Disease. Asian Pacific Journal Cancer Preventions, 7; p.22-31

Marcucci MC, Ferreres F, Garc a-Viguera C, Bankova VS, De Castro SL, Dantas AP et al,. 2001. Phenolic Compounds from Brazilian Propolis with Pharmacological Activities. J Ethnopharmacol; 74: p.105-12

Mot AC, Damian G, Sarbu C, Silaghi DR. 2009. Redox Reactivity in Propolis: Direct Detection of Free Radicals in Basic Medium and Interaction with Hemoglobin. Department of Chemistry and Chemical Engineering, 'Babes-Bolyai' University, Cluj-Napoca, Romania. Journal Medicine Food, 14(6):267-74.

Nakajima Y, Tsuruma K, Shimazawa M, Mishima S, Hara H. 2009. Comparison of Bee Products Based on Assays of Antioxidant Capacities. BMC Complementary and Alternative Medicine, 9:4

Orsi RO, Funari SR, Soares A, Salvi SA, Oliveira SL, Sforcin JM et al. 2000. Immunomodulatory Action of Propolis on Macrophage Activation. Journal of Venomous Animals and Toxin, 6 (2): 205-19.

Raso GM, Meli R, Carlo G, Pacilio M, Carlo R. 2001. Inhibition of Inducible Nitric Oxide Synthase and Cyclooxygenase-2 Expression by Flavonoids in Macrophage J774A.1. Life Sci, 68(8):921-31.

Reed JC. 2000. Mechanism of Apoptosis. Am J Pathol, 157: 1415-1430.

Salatino A, Teixeira EW, Negri G, and Message D. 2005. Origin and Chemical Variation of Brazilian Propolis. Evid Based Complement Alternat Med, 2 (1): p.33-8.

Scholefield JH dan Eng C. 2014. Colorectal Cancer, Diagnosis, and Clinical Management. New Jersey, Wiley Blackwell.

Shimizu S, Narita M, Tsujimoto Y. 1999. Bcl-2 family proteins regulate the release of apoptogenic cytochrome $\mathrm{C}$ by the mitochondrial channel VDAC. Nature, 399:483-487.

Story M, Kodym R. 1998. Signal Transduction during Apoptosis; Implications for Cancer Therapy. Front Biosci. 23: 365-75.

Stupack DG. 2013. Caspase-8 as a Therapeutic Target in Cancer. Cancer Lett. 28; 332(2): 133-140.

Wang X dan Zhang Y. 2014. Targeting mTOR network in colorectal cancer therapy. World J Gastroenterol. 20(15): 4178-4188.

Young A, Hobbs R, Kerr D. 2011. ABC of colorectal cancer, 2nd ed. Oxford, Willey Blackwell Press.

Zaeemzadeh N, Hemmati A, Arzi A, Jalal M, Rashidi. 2011. Protective Effect of Caffeic Acid Phenethyl Ester (CAPE) on Amiodarone-Induced Pulmonary Fibrosis in Rat. Iranian Jour of Pharm Research; 10 (2):p. 321-8. 